\title{
Effect of Temperature on Metabolism of Simetryn in Rice Cultivars****
}

\author{
Hiroshi Matsumoto and Kozo Ishizuka
}

Institute of Applied Biochemistry, The University of Tsukuba, Ibaraki 305, Japan

Rice cultivars vary greatly in their sensitivity to the herbicide simetryn $[2,4$-bis (ethylamino)-6-methylthio-1, 3, 5-triazine ]. Although japonica-type cultivars generally show tolerance to simetryn, it has been reported that injury or growth retardation has occured in rice seedlings in sandy paddy fields under high temperature conditions ${ }^{7)}$. The mode of action of the herbicide is affected by various environmental factors, particularly temperature.

In a previous paper ${ }^{1)}$, absorption and translocation of ${ }^{14} \mathrm{C}$-simetryn in several rice cultivars were surveyed under high $\left(32^{\circ} \mathrm{C}\right.$ day and $27^{\circ} \mathrm{C}$ night) and low $\left(25^{\circ} \mathrm{C}\right.$ day and $20^{\circ} \mathrm{C}$ night) temperatures. Cultivars tested were selected from japonica- and indica-types and their hybrid. The rates of absorption were increased by increasing temperature in all cultivars. Translocation rates were observed for several hours after treatment in japonica-type cultivars (Nihonbare and Bluebell). The rates of accumulation of ${ }^{14} \mathrm{C}$ radioactivity with increasing temperature in shoots differed among cultivars, and were most remarkable in japonica-type which were more tolerant to simetryn.

The metabolism of simetryn in several cultivars was surveyed at $25^{\circ} \mathrm{C}$ and higher metabolic activity was shown in japonica-type compared with the others ${ }^{2}$. In this paper, the effect of temperature on simetryn metabolic activity is reported in two rice cultivars which have differential sensitivity to the substance.

\section{Materials and Methods}

Two rice cultivars, Nihonbare (japonicatype, tolerant) and IR-8 (indica-type, susceptible) were used for the experiment. Plants were grown to the 3.2 to 3.4 -leaf stage in a controlled growth chamber as previously reported $^{11}$. Two days before simetryn treatment, the plants were transferred to growth chambers which maintained respective day/night temperatures of $32^{\circ} / 27^{\circ} \mathrm{C}$ and $25^{\circ} /$ $20^{\circ} \mathrm{C}$. Relative humidity was $60 \%$ and light intensity was maintained at 22 klux in both chambers.

At the beginning of treatment, roots of both cultivars were placed in $9.39 \times 10^{-6} \mathrm{M}$ of ${ }^{14} \mathrm{C}$-simetryn (specific activity of $3.62 \mathrm{mCi}$ / $\mathrm{mM}$ ) solution at either $32^{\circ}$ or $25^{\circ} \mathrm{C}$ for 2 hours. Immediately after this treatment, a part of each plant was harvested as an initial sample and the remains were transferred to a simetryn-free nutrient solution and harvested thereafter at several time intervals.

At harvest, the plants were removed from the solution, rinsed with distilled water and blotted dry with absorbent paper. They were then sectioned into roots and shoots. After determination of its fresh weight, each plant part was ground in $10 \mathrm{ml}$ of $90 \%$ methanol per gram of fresh tissue with a high speed homogenizer. The homogenates were filtered in vacuo and the residue was extracted twice with the same volume of $90 \%$

* This work was supported by a Grant in Aid for Fundamental Scientific Research from the Ministry of Education of Japan.

** This work was reported at the 22nd Annual Meeting of the Weed Science Society of Japan, 1983. 
of methanol. The filtrates were combined, their volume was measured and their radioactivity was determined by a liquid scintillation spectrometer. The combined solutions were concentrated in vacuo at $40^{\circ} \mathrm{C}$. The concentrated solutions were partitioned three times between water and dichloromethane to separate unchanged simetryn, its dealkylated compounds and other dichloromethane-soluble metabolites from polar metabolites. Aliquots of the aqueous and dichloromethane fractions were assayed for radioactivity. Radioactivity in a non-extractable residue was determined by a sample combustion method as previously
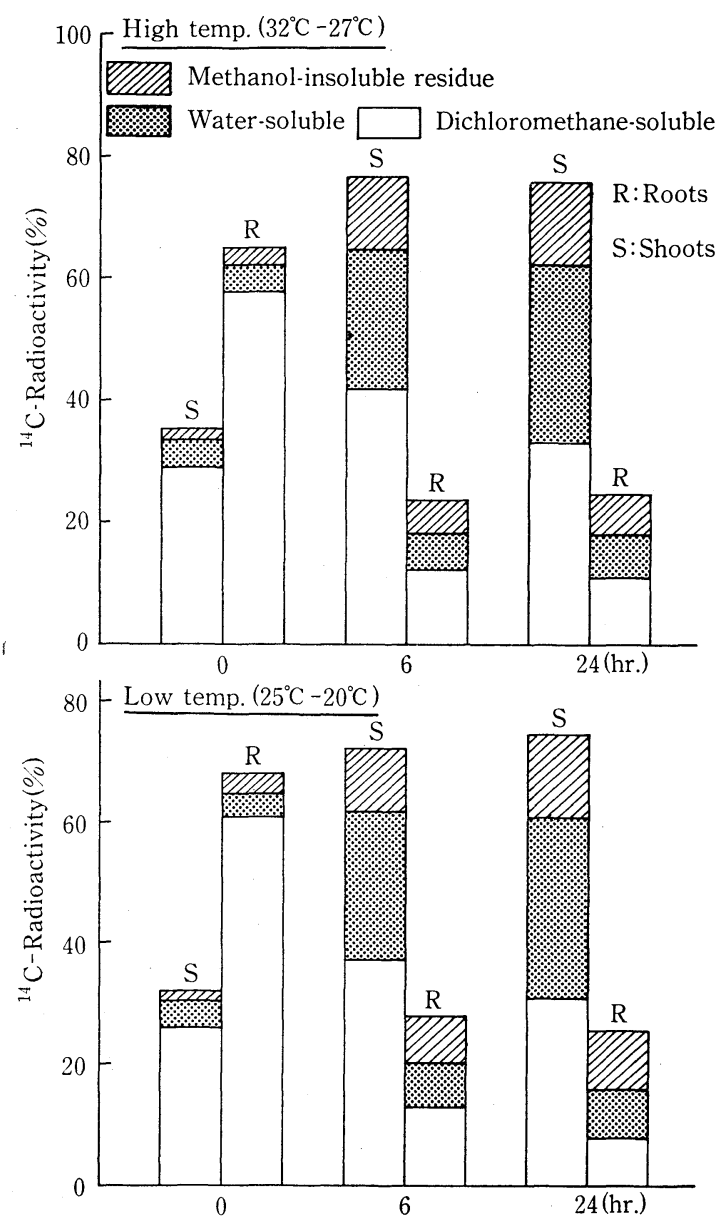

Fig. 1. Distribution of ${ }^{14} \mathrm{C}$ derived from ${ }^{14} \mathrm{C}$ simetryn into each fraction in cultivar Nihonbare under different temperature conditions. reported ${ }^{4)}$. Metabolites of simetryn in the cultivars were investigated by thin-layer chromatography as previously described ${ }^{4}$. The experiment was conducted with 2 replicates of 30 plants each.

\section{Results and Discussion}

Metabolism of simetryn incorporated in rice plants was traced sequentially by extraction with methanol and fractionation with water and dichloromethane. The ${ }^{14} \mathrm{C}$-radioactivity in each fraction originating from root-applied ${ }^{14} \mathrm{C}$-simetryn including the methanol-insoluble residue, was traced and the distribution is

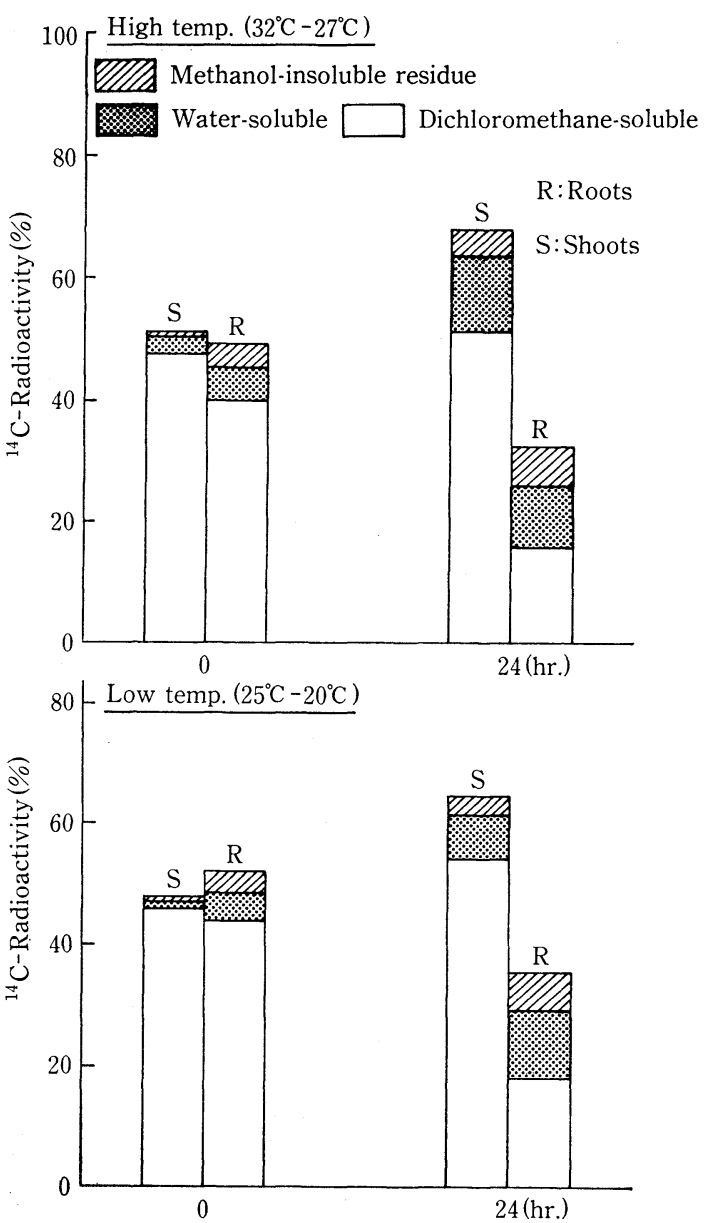

Fig. 2. Distribution of ${ }^{14} \mathrm{C}$ derived from ${ }^{14} \mathrm{C}-$ simetryn into each fraction in cultivar IR-8 under different temperature conditions. 
shown in Figures 1 and 2.

In the cultivar Nihonbare, simetryn was metabolized at a considerably high rate to water-soluble and methanol-insoluble metabolites; this was the same result obtained previously ${ }^{2,5)}$. Little difference was observed in rates of metabolic breakdown of simetryn between plants treated at high and low temperatures. At 24 hours after treatment, about $30 \%$ of the total absorbed ${ }^{14} \mathrm{C}$ was detected in the dicloromethane-soluble fraction in shoots of both temperature treatments.

Although cultivar IR-8 also matabolized simetryn to water-soluble and methanolinsoluble metabolites, the rate of metabolism was much slower than that in cultivar Nihonbare. These results agreed with a previous paper ${ }^{2)}$, and the low rate of metabolism was considered to be responsible for susceptibility of the cultivar to simetryn. Little difference in the percentage of each IR- 8 fraction between plants treated at high and low temperatures was observed, as was true of the Nihonbare. After 24 hours, $51 \%$ and $54 \%$ of the total absorbed ${ }^{14} \mathrm{C}$ still remained in dichloromethane-soluble fraction in shoots under high and low temperature treatment, respectively.

The authors have already shown that the mode of action of simetryn is to inhibit photosynthetic processes where unchanged simetryn and its mono-dealkylated compound acted as inhibitors ${ }^{3,6)}$. As the concentration of these compounds in photosynthesizing shoots was considered to determine the extent of injury, their metabolic fates in shoots of both cultivars treated at different temperatures were investigated. The concentration of radioactivity in shoots and distribution into each fraction are shown in Table 1 . It was shown that dichloromethane-soluble fractions of both cultivars were converted into watersoluble and methanol-insoluble derivatives at the same rate by both temperature treatments.

Percentages of unchanged simetryn and its main metabolites in the dichloromethanesoluble fraction found in shoots are shown in Table 2. In cultivar Nihonbare, simetryn was degraded at equal rates in both temperature treatments. The herbicide was degraded so rapidly that 24 hours after treatment only $28 \%$ of the total radioactivity in shoots was detected as phytotoxic compounds (simetryn plus mono-dealkylated simetryn). Although no big difference in the rate of simetryn degradation between high and low temperature treatments was found in cultivar IR-8, the rates were much slower than those in

Table 1. Distribution of radioactivity derived from ${ }^{14} \mathrm{C}$-simetryn in shoots of cultivars Nihonbare and IR-8 under different temperature conditions.

\begin{tabular}{|c|c|c|c|c|c|c|}
\hline \multirow{2}{*}{ Cultivar } & \multirow{2}{*}{$\begin{array}{l}\text { Temp. } \\
\text { (day-night) }\end{array}$} & \multirow{2}{*}{$\begin{array}{l}\text { Time } \\
\text { (hr.) }\end{array}$} & \multirow{2}{*}{$\begin{array}{l}\text { *Concentration of }{ }^{14} \mathrm{C} \\
\text { in shoots } \\
\quad(\mu \mathrm{g} / \mathrm{g} \text { fresh wt. })\end{array}$} & \multicolumn{3}{|c|}{ Fractions } \\
\hline & & & & $\mathrm{CH}_{2} \mathrm{Cl}_{2}$ & $\mathrm{H}_{2} \mathrm{O}$ & Insoluble \\
\hline \multirow{6}{*}{ Nihonbare } & \multirow{3}{*}{$\begin{array}{l}\text { High } \\
\left(32-27^{\circ} \mathrm{C}\right)\end{array}$} & $* * 0$ & 0.91 & $82.6 \%$ & $13.0 \%$ & $4.4 \%$ \\
\hline & & 6 & 1. 62 & 54.6 & 31.0 & 14.4 \\
\hline & & 24 & 1. 44 & 42.1 & 39.4 & 18.5 \\
\hline & \multirow{3}{*}{$\begin{array}{l}\text { Low } \\
\left(25-20^{\circ} \mathrm{C}\right)\end{array}$} & 0 & 0.91 & 81.0 & 13.7 & 5.3 \\
\hline & & 6 & 1. 20 & 50.4 & 33.4 & 16.2 \\
\hline & & 24 & 1.26 & 41.4 & 39.8 & 18.8 \\
\hline \multirow{4}{*}{ IR-8 } & \multirow{2}{*}{$\begin{array}{l}\text { High } \\
\left(32-27^{\circ} \mathrm{C}\right)\end{array}$} & 0 & 0.97 & 95.1 & 3.5 & 1.4 \\
\hline & & 24 & 0.87 & 75.7 & 18.6 & 5.7 \\
\hline & \multirow{2}{*}{$\begin{array}{l}\text { Low } \\
\left(25-20^{\circ} \mathrm{C}\right)\end{array}$} & 0 & 0.97 & 96.2 & 2.4 & 1. 4 \\
\hline & & 24 & 0.82 & 83.9 & 11.1 & 5. 0 \\
\hline
\end{tabular}

* Concentrations were calculated as simetryn equivalent.

** Plants which absorbed ${ }^{14} \mathrm{C}$-simetryn for 2 hours were harvested as 0 time sample. 
Table 2. Metabolites of ${ }^{14} \mathrm{C}$-simetryn in dichloromethane-soluble fractions under different temperature conditions.

\begin{tabular}{|c|c|c|c|c|c|c|c|c|}
\hline \multirow{2}{*}{ Cultivar } & \multirow{2}{*}{$\begin{array}{l}\text { Temp. } \\
\text { (day-night) }\end{array}$} & \multirow{2}{*}{$\begin{array}{l}\text { Time } \\
\text { (hr) }\end{array}$} & \multicolumn{6}{|c|}{${ }^{14} \mathrm{C}-$ Radioactivity } \\
\hline & & & Simetryn & $* \mathrm{MDS}$ & $* * \mathrm{DDS}$ & Origin & Others & Total \\
\hline \multirow{6}{*}{ Nihonbare } & \multirow{3}{*}{$\begin{array}{l}\text { High } \\
\left(32-27^{\circ} \mathrm{C}\right)\end{array}$} & $* * * 0$ & $55.2 \%$ & $6.9 \%$ & $0.2 \%$ & $9.9 \%$ & $10.4 \%$ & $82.6 \%$ \\
\hline & & 6 & 33.2 & 5.2 & 0.2 & 7.9 & 8.1 & 54.6 \\
\hline & & 24 & 20.8 & 6.9 & 0.4 & 8.5 & 5.5 & 42.1 \\
\hline & \multirow{3}{*}{$\begin{array}{l}\text { Low } \\
\left(25-20^{\circ} \mathrm{C}\right)\end{array}$} & 0 & 56.5 & 5.4 & 0.2 & 5.9 & 13. 0 & 81.0 \\
\hline & & 6 & 30.0 & 5.5 & 0.4 & 6.8 & 7.7 & 50.4 \\
\hline & & 24 & 21.5 & 6.7 & 0.4 & 7.4 & 5.3 & 41.3 \\
\hline \multirow{4}{*}{ IR-8 } & \multirow{2}{*}{$\begin{array}{l}\text { High } \\
\left(32-27^{\circ} \mathrm{C}\right)\end{array}$} & 0 & 67.9 & 20.9 & 1.2 & 2.0 & 3.1 & 95.1 \\
\hline & & 24 & 53.5 & 18.0 & 1.1 & 1.5 & 1.6 & 75.7 \\
\hline & \multirow{2}{*}{$\begin{array}{l}\text { Low } \\
\left(25-20^{\circ} \mathrm{C}\right)\end{array}$} & 0 & 85.9 & 6.0 & n. d. & 2.1 & 2.2 & 96.2 \\
\hline & & 24 & 54.0 & 23.7 & 1.5 & 3.1 & 1.6 & 83.9 \\
\hline
\end{tabular}

* MDS : Mono-dealkylated simetryn (2-amino-4-ethylamino-6-methylthio-1, 3, 5-triazine)

** DDS : Di-dealkylated simetryn (2,4-diamino-6-methylthio-1, 3, 5-triazine)

*** Plants which absorbed ${ }^{14} \mathrm{C}$-simetryn for 2 hours were harvested as 0 time sample.

Nihonbare: $72 \%$ and $78 \%$ respectively.

A greater percentage of mono-dealkylated simetryn was detected in cultivar IR-8 than in Nihonbare. Barnyardgrass is very susceptible to simetryn and the main metabolic pathway of the herbicide is reportedly via dealkylation ${ }^{5)}$. The pattern of simetryn metabolism in cultivar IR-8 is similar to that in barnyardgrass.

These results showed that there was little difference in the rate of metabolic reaciton of simetryn between the two temperature treatments. They also indicate that the metabolic activity of neither cultivar was affected by temperature increase and that therefore temperature variation is not a factor in this activity.

Absorption and translocation studies previously showed that high temperature enhanced the accumulation of ${ }^{14} \mathrm{C}$ in shoots of japonicatype cultivars ${ }^{1)}$. It was concluded that japonica-type cultivars were more sensitive to temperature variation than other cultivars, and their increasing phytotoxicity of simetryn with increasing temperature resulted from increased absorption and translocation of the herbicide. The increased foliar accumulation with increasing temperature was probably a reflection of an increase in transpiration whereby the herbicide was carried in the transpiration stream and distributed throughout the shoots ${ }^{5}$.

The sensitivity of absorption and translocation of simetryn to temperature variation clearly differed among the cultivars and it was suggested that part of this variation was due to the genetic difference in cultivar adaptation to different temperatures. Since temperature causes the great effect on simetryn accumulation in shoots previously shown ${ }^{1}$, it is possible that, under field conditions japonica-type rice cultivars could sustain injury at high temperatures mainly because of increased absorption and translocation.

\section{Summary}

The effect of temperature variation on the metabolic activity of simetryn [2, 4-bis (ethylamino)-6-methylthio-1, 3,5-triazine] in rice cultivars Nihonbare (japonica-type, tolerant) and IR-8 (indica-type, susceptible) was investigated.

Although the cultivar Nihonbare metabolized simetryn effectively to water-soluble and methanol-insoluble compounds, little difference was observed in the percentage of 
metabolic products between plants treated at a high temperature $\left(32^{\circ} \mathrm{C}\right.$ day and $27^{\circ} \mathrm{C}$ night $)$ and at a low temperature $\left(25^{\circ} \mathrm{C}\right.$ day and $20^{\circ} \mathrm{C}$ night).

The metabolic activity of cultivar IR- 8 was much inferior to that of cultivar Nihonbare. There was also little difference in the percentage of metabolites in cultivar IR- 8 between high and low temperature treatments.

Temperature variation had little effect on the metabolic activity of the cultivars. It was concluded that the increased phytotoxicity of simetryn when the temperature was raised was the result of the increased absorption and translocation of the herbicide.

\section{References}

1) Ishizuka K., H. Матsumoto and Y. Kakumoto: Weed Res. (Japan) 29 (2) 116 122 (1984).

2) Ishizuka K., H. Matsumoto aud T. Imahase: Weed Res. (Japan) 28 (Suppl.), 83 84 (1983) (in Japanese).

3) Matsumoto H. and K. Ishizuka: Weed Res. (Japan) 25 (Suppl.), 115 116(1980)(in Japanese).

4) Матsumoto H. and K. Ishizuka: Weed Res. (Japan) 25, 185 193 (1980).

5) Матsumoto $H$. and K. Ishizuka: Weed Res. (Japan) 26, 135 141 (1981).

6) Матsumoto H. and K. Ishizuka: Weed Res. (Japan) 27, 91 97 (1982).

7) Miyahara M.: Proc. of 4th Symposium of Weed Sci. Soc. Japan 1 22 (1979) (in Japanese).

(Received February 4, 1984)

\section{イネ品種におけるシメトリンの代謝に及ぼす温度の影響}

\section{松本 宏・石塚皓造 筑波大学 応用生物化学系}

摘 要

本研究は除草剤シメトリンに対するイネ各品種の有する生理・生化学的性質が, 温度変化に伴ってどのように変化 するかを調べる一環として，前報において報告した吸収，移行の変化にひきつづき，各品種の有するシメトリンの分 解・代謝能の変化について検討したものである。

イネの中から日本型でシメトリンに対して抵抗性である品種「日本晴」, インド型で感受性の品種「IR-8」を選び, 両品種とも水耕法により $3.2 \sim 3.4$ 葉期まで生育したものを供試した。処理 2 日前に温度の異なった人工気象室 (高温 区：昼 $32^{\circ} \mathrm{C}$, 夜 $27^{\circ} \mathrm{C}$, 低温区：昼 $25^{\circ} \mathrm{C}$, 夜 $\left.20^{\circ} \mathrm{C}\right)$ 亿移し，シメトリンの处理は，各品種の根部をそれぞれ $9.39 \times 10^{-6} \mathrm{M}$ の ${ }^{14} \mathrm{C}$-シメトリン水溶液 $(13.6 \mu \mathrm{Ci})$ に 2 時間浸漬することにより行った。処理終了後はシメトリンを含まない水耕 液に移して栽培した。処理は各 30 個体を 1 連とし 2 連で行った。

所定時間後に採取し根部と茎葉部に分け，それぞれを $90 \%$ タノール中で磨砕した。磨砕液はろ過し，残渣はさら に $90 \%$ メタノールで 2 度抽出して抽出液を得た。抽出液はその総放射能を液体シンチレーションスペクトロメーター で測定し，残渣中の放射能は自動試料燃燒装置による処理を行って同様に測定した。その後抽出液を減圧濃縮し，水 とジクロルメタンで分配を行い，それぞれに可溶の画分を得た。ジクロルメタン画分は薄層クロマトグラフィーによ る分析を行った。

「日本晴」においては，シメトリン由来の放射能は時間の経過と共に，水可溶性画分および残渣画分への変化が顕 著であった。しかし，処理温度の違いによるこれら画分への変化の割合には差はみられなかった (Fig. 1)。「IR-8」 においては，水可溶性画分および残渣画分への変化の割合は小さかった。また，温度による差は認められなかった (Fig. 2)。 
シメトリンの作用点は光合成の明反応の阻害と考えられるので, 茎葉中における放射能濃度について検討した (Table 1)。茎葉部中の濃度は「日本晴」では高温区において高い傾向を示したが，温度処理区間で各画分への変化 割合には差は認められなかった。「IR-8」においては処理温度の違いによる茎葉内の濃度変化はみられず，また，各 画分への変化割合にも大きな差はなかった。

次に茎葉中における各化合物および分解・代謝産物について検討した（Table 2)。「日本晴」の茎葉中においては シメトリンの分解が迅速に進行し, 光合成阻害活性を有する親化合物とそのモノ脱エチル体の総量は, 処理24時間後

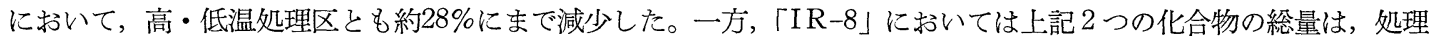
24時間後において高温処理区で72\%，低温処理区で78\%であった。また，「IR-8」においてはモノ脱エチル体が多く 検出され，この分解経路は先に報告したシメトリンに対して感受性の高いタイヌビエのそれと似ていた。

以上の結果から，これらの品種のシメトリン分解・代謝能は，温度変化によってほとんど影響を受けないことが明 らかとなり，先に報告した日本型イネにみられた温度上昇に伴う吸収・移行の速度増加の結果としておこる茎葉内濃 度の上昇が，葉害発生の主因と考えられた。また，この一連の研究によってイネの有するシメトリンに対する生理的 性質の温度変化に対する感応性は，品種によって顕著に異なることが明らかにされた。 